\title{
Effect Of Salt Stress On The Growth And Nitrogen Assimilation Of Arachis Hypogea (L) (Groundnut)
}

\author{
Osuagwu, G.G.E. and Udogu, O, F. \\ Department of Plant Sciences and Biotechnology,Michael Okpara University of Agriculture, UmudikeUmuahia \\ Abia State, Nigeria.
}

\begin{abstract}
The effect of salt stress on the growth and nitrogen assimilation of Arachis hypogea (groundnut) was investigated. A. hypogea cultivitated in planting buckets were treated with saline water at $0.02 \mathrm{~mol} / \mathrm{L}, 0.03 \mathrm{~mol} / \mathrm{L}$, $0.07 \mathrm{~mol} / \mathrm{L}$ and $0.1 \mathrm{~mol} / \mathrm{L}$. Plants not treated with saline water served as control. Treatment occured 3 weeks after seed germination and was carried out once. The study took place for 4 months. Salt stress significantly $(P<0.05)$ affected the growth and nitrogen assimilation of A. hypogea.At higher salt $(\mathrm{NaCl})$ concentration $(0.07 \mathrm{ml} / \mathrm{L}$ and $0.1 \mathrm{~mol} / \mathrm{L})$, the lenght of shoot, numbers of leaves, number of branches, number of pods, length of pod, pod biomass, root biomass, shoot biomass and the nitrogen content of the plant's leaf and soil were significantly $(P<.0 .05)$ reduced. However. At lower concentration, $(0.01$ to $0.03 \mathrm{ml} / \mathrm{L})$ the effect of salt stress on these parameters was not significant. The reduction in growth and nitrogen assimilation of A. hypogea as a result of salt stress might be due to the deleterous effect of salt stress on the cellular as well as all other aspects of plant metabolism. The results obtained were discussed in the light of current literatures.
\end{abstract}

Key words: Salt stress, growth, Nitrogen assimilation, Arachis hypogea.

\section{Introduction:}

Soil salinity is one of the largest constrains to plant productivity and specifically to global food production[23]. Nearly one third of the worlds irrigated agricultural land is saline and current estimates put salt affected soils at $400-950$ million hectares[31]. Salinity of the soils results to high level of accumulation of the major cations and anions in the soils which can lower crop productivity[28].

Research findings have indicated that salt stress may lead to decrease in dry matter yield, water and osmotic stress, chlorophyll content and gas exchange variables[9;13;15].It may also cause ions and mineral imbalance as well as several other negative impacts on physiological processes in plants $[12 ; 13 ; 15]$. All plants undergo supressive growth at high concentration of salt which vary extensivily among different plant species[22].Importantcellular and metabolic processes, such as celldivision, cell expansion, photosynthesis, protein synthesis, lipid metabolism and energy in plants are found to be affected by salt stress[3;22].

Salinity adversely affects germination, growth, physiology and productivity by reducing the ability of plants to take up water causing imbalance in osmotic potential, ionic equilibrium and nutrient up take[20].Furthermore, salt stress has been know to cause decreased biosynthesis of chlorophyll and lead to inefficiency of photosynthesis[18], which will ultimately lead to lowered economic productivity[5]The decline in photosynthesis due to salt stress could be due to lower stomatal conductance, depression in carbon up take and metabolism, inhibition of photochemical capacity or a combination of these factors[17].

Water stress tends to pose a significant limitation to productivity of legumes due to its adverse effects on the growth of the plants. It also affects the root nodule bacteria and their nitrogen fixation capacity[29].Legume cultivars behave differently under saline conditions. Their responses is dependent of a number of factors which include the concentration of salt in the soil solution[8].

Arachis hypogea belongs to Fabacea (Leguminosae) and the papillionace sub-family. It is a perennial or annual legume with three or four leaflets, stipulated leaves, papillonate flowers and subterranean fruit[11].The plants are low sub-erect herbs often prostate and even creeping. The stem is generally angular, pubscent and solid with large central pith in early stage and stems tend to become hollow and cylindrical and shed most of their hairs expecially on lower internode[11].A.hypogea has many uses. The can be eaten raw, used in recipes, made intosolvent and oils, medicine,texitile materials and pea butter[26].

The mangrove swamp region which occurs in the Niger Delta area of Nnigeria contains saline soil. Many crop plants cannot survive in this type of environment because of the high salinity and chikoko soil. The mangrove forest extends from Badagry in the West to Calabar in the East covering a total area of 10,000 $\mathrm{Km}^{2}$ along the coast[30]. This research therefore, investigated the performance of A. hypogea ((groundnut) on different concentrations of saline water in order to determine the level of its tolerance to salt stress in the view of utiliizing this wide expanse of land for the cultivation of the crop based on its economic importance. 
Plant materials

\section{Materials amd Methods:}

Arachis hypogea seeds (grade one variety) was obtained from the Service unit of the College of Crop and Soil Sciences, Michael Okpara University of Agriculture, Umudike, Umuahia and were tested for viability[1].The plants were cultivated in 25 plastic planting buckets $2 / 3$ filled with soil obtained from the University farm. Treatments were carried out in five reflicates of each treatment. Four levels of saline solutions $0.02 \mathrm{ml} / \mathrm{L}, 0.03 \mathrm{~mol} / \mathrm{L}, 0.07 \mathrm{~mol} / \mathrm{L}$ and $0.1 \mathrm{~mol} / \mathrm{L}$ prepared from sodium chloride obtained from the Plant Science and Biotechnology laboratory according to Motohari et al.[16],method was used for the study. No saline solution treatment served as control.Treatment occured three weeks after seedling emergence and it was done once. The investigation was carried out for four months.

Data collection started two weeks after treatment. Plant height and lenght of pots were determined using $30 \mathrm{~cm}$ meter rule and the weight of pods and biomass of roots and shoots was taken using a sensitive electric balance after been dried in selectal model 150 - 9001 oven. The number of flowers, number of pods and branches was obtained using manual count. The research was carried in the Green House of the College of Crop and Soil Sciences, Michael Okpara University of Agriculture, Umudike, Umuahia Abia State, Nigeria.

\section{Determination of the percentage Nitrogen content:}

The percentage nigrogen content of both the soil and plant materials was determined using kjeldahl method described by AOAC,[2]

$0.5 \mathrm{gm}$ of each sample was mixed with $10 \mathrm{ml}$ concentrated sulphuric acid (Analytic Reagent grade) in a Kjeldahl digestion flask. A tablet of selenium catalyst was added into the flask and was digested in a fume cup board until a clear solution was obtained. Blank control was formed using digesting acid and reagents without samples . $100 \mathrm{ml}$ of each digested sample was mixed with equal volume of $45 \%$ sodium hydroxide solution in kjeldahl distilling unit. The mixture was distilled and the distillate collected in $10 \mathrm{ml}$ of $4 \%$ Boric acid solution containg 3 drops of mixed indicators(bromocresol green and methylred). $50 \mathrm{ml}$ of the distillates obtained was titrated against 0.02 in sulphric acid solution and titre values obtained.

The percentage Niterogen content was calculated using the formula

\begin{tabular}{lllllllllll}
$\%$ & $\mathrm{~N}_{2}$ & $=$ & & $(100$ & $\mathrm{X}$ & $\mathrm{N}$ & $\mathrm{X}$ & 14 & $\mathrm{X}$ & $\mathrm{Vf})$ \\
\hline
\end{tabular}
$\mathrm{W} \times 1000 \times \mathrm{Va}$

Where : $\quad \mathrm{W}=$ Weight of sample analysed

$\mathrm{N}=$ Concentration of $\mathrm{H}_{2} \mathrm{~S} 04$

$\mathrm{Vf}=$ Total Volume of digest

$\mathrm{Va}=\quad$ Volmue of digest distilled.

Statistical Analysis:

The design of this study was the complete randomized design in five replicates of each treatment. Analysis of variance was used to determine the significant level and least significant difference (LSD) at 0.05 probabilitty level was used to determine the difference among treatments.

\section{Results and Discussions:}

Salt stress had significant effect on the growth and nitrogen assimilation of Arachis hypogea (Tables 1 $-4)$

\section{Effect of Salt Stress on the Vegetative Growth of A. hypogea:}

Salt stress caused a significant decrease $(\mathrm{P} .<0.05)$ in the height of plants, number of branches and number of leaves of A. hypogea (Table 1). The severity of the effect increased with increase in the concentration of the salt stress. This observations tend to agree with the reports of Ramoliya et al.,[24] Parida et al.,[21],Maggio et al.,[15] and Neocleous and Vasilakakis[19], which showed that salt stress caused significant decrease in the vegetative growth of some plants.

The shoot and root biomass of A. hypogea (groundnut) were significantly $(\mathrm{P} .<0.05)$ decreased by salt stress (Table 2). The decrease in biomass of the plants increased with increase inthe concentration of the salt stress. Reduction in the biomass of Phaseolus vulgaris as a result of salt stress was also reported by Elsheikh and Wood,[10] and Khanna - Chopra and Sinha,[14].

The reduction in vegetative growth of A. hypogea due to the effect of salt stress might be due to the effect of salinity on important cellular and metabolic processes in plants which include cell division, cell expansion, photosynthesis, protein synthesis, lipid metabolism[22], which might be due to the inability of the plants to take up water causing imbalance in osimotic potential, ionic equilibrum and nutrient up take[20].Salt stress is recorded to cause decreased biosynthesis of chlorophyll and inefficiency of photosynthesis which ultimately lead to lowered productivity[18]. Decline in photosynthesis due to salinity might be due to lowered 
stomatal conductance, depression in carbon up take and metabolism, inhibition of photochemical capacity or the combination of all these factors[17].

\section{Effect of salinity on the Reproductive Process of A. hypogea:}

The number of flowers, number of pods, lenght of pods, and dry weight of the seeds were significantly $(\mathrm{P}<0.05)$ reduced by salt stress (Table 3$)$. The reduction observed as a result of salt stress might be due to disruption of physiological processes in plants by salt stress[13].Boscaiu et al.[4], also reported that high salinities had a negative effect on fruiting of plants due to progressive reduction of pollen fertility, seed set and seed viability. Significant decrease in flowering and fruit yield in plants due to salt stress was reported by other researchers $[4 ; 6 ; 7]$.

The degree of salt stress affected the rate of its effect on flowering and fruiting of A. hypogea. As the salinity increases the rate of its effect also increased. This observation tends to agree with the report of Boscaiu et al.[4], who showed that at higher salinities the effect of salt stress was more prominent.

\section{Effect of Salt Stress on Nitrogen Assimilation of Plants and Soil:}

Higher salt concentration significant $(\mathrm{P}<0.05)$ reduced the amount of nitogen fixed into soil and also taken up by the roots from the soil by A. hypogea (Table 4). The observed reduction in nitrogen content in both the soil and the plant might be due to the sensitivity of nitrogenase activity to salt stress. During salt stress in plants, nitrate reductase activity decrease and nitrogen fixation inhibited by reducing nodulation[27]. Salt stress also caused severe decrease in nitrate concentration and activity of nitrate reductase[24].

Findings from this study indicate that salt stresshad negative impact on both the vegetative and reproductive growth of A. hypogea as well as its ability to fix and assimilate nitrogen. At lower salinity, the A. Hypogea 'grade one variety was not significantly affected, hence could be cultivated in areas of low salinity.

Table 1: The effect of salt stress on the length of shoot, number of leaves and number ofbranches of Arachis hypogea(groundnut).

\begin{tabular}{llll}
\hline $\begin{array}{l}\text { Concentration } \\
(\mathbf{m o l} / \mathbf{L})\end{array}$ & Length of shoot $(\mathbf{c m})$ & Number of branches & Number of leaves \\
\hline Control & $55.84 \pm 1.36^{\mathrm{a}}$ & $32.75 \pm 0.96^{\mathrm{a}}$ & $126.50 \pm 8.19^{\mathrm{a}}$ \\
0.02 & $51.93 \pm 3.32^{\mathrm{ab}}$ & $31.75 \pm 2.63^{\mathrm{ab}}$ & $127.25 \pm 10.18^{\mathrm{a}}$ \\
0.03 & $53.58 \pm 0.95^{\mathrm{ab}}$ & $29.00 \pm 2.58^{\mathrm{bc}}$ & $91.50 \pm 16.68^{\mathrm{c}}$ \\
0.07 & $51.00 \pm 1.95^{\mathrm{b}}$ & $29.25 \pm 1.50^{\mathrm{abc}}$ & $98.25 \pm 9.74^{\mathrm{c}}$ \\
0.10 & $48.90 \pm 3.47 \mathrm{c}$ & $27.75 \pm 3.10^{\mathrm{c}}$ & $94.50 \pm 12.58^{\mathrm{c}}$ \\
\hline
\end{tabular}

Table 2: Effect of salt stress on the root and shoot biomass of A. hypogea (groundnut).

\begin{tabular}{|c|c|c|c|c|}
\hline \multirow{2}{*}{$\begin{array}{l}\text { Concentration } \\
(\mathrm{mol} / \mathrm{L})\end{array}$} & \multicolumn{2}{|l|}{ Root Biomass (g) } & \multicolumn{2}{|c|}{ Shoot Biomass (g) } \\
\hline & Fresh weight & Dry weight & Fresh weight & Dry weight \\
\hline Control & $0.83 \pm 0.27^{\mathrm{a}}$ & $0.27 \pm 0.73^{\mathrm{a}}$ & $32.72 \pm 2.74^{\mathrm{a}}$ & $\mathbf{8 . 5 4} \pm 0.89^{\mathrm{a}}$ \\
\hline 0.02 & $1.08 \pm 0.21^{\mathrm{a}}$ & $0.24 \pm 0.77^{\mathrm{ab}}$ & $31.33 \pm 4.05^{\mathrm{a}}$ & $7.76 \pm 1.46^{\mathrm{a}}$ \\
\hline 0.03 & $0.75 \pm 0.27^{\mathrm{a}}$ & $0.13 \pm 0.02^{\mathrm{c}}$ & $28.28 \pm 6.64^{\mathrm{ab}}$ & $6.82 \pm 1.42^{\mathrm{a}}$ \\
\hline 0.07 & $0.99 \pm 0.44^{\mathrm{a}}$ & $0.17 \pm 0.06^{\mathrm{bc}}$ & $26.64 \pm 7.50^{\mathrm{ab}}$ & $6.12 \pm 2.43^{\mathrm{ab}}$ \\
\hline 0.1 & $0.87 \pm 0.29^{\mathrm{a}}$ & $0.11 \pm 0.03^{\mathrm{c}}$ & $\mathbf{2 0 . 5 5} \pm 4.91^{\mathrm{b}}$ & $\mathbf{3 . 8 5} \pm 1.33^{\mathrm{b}}$ \\
\hline
\end{tabular}

Table 3: Effect of salt stress on the number of flowers, length of pod, number of pods and seed dry weight

\begin{tabular}{|c|c|c|c|c|}
\hline Control & $2.23 \pm 0.04^{\mathrm{a}}$ & $3.50 \pm 0.41^{\mathrm{a}}$ & $7.50 \pm 0.58^{\mathrm{a}}$ & $1.10 \pm 0.86^{\mathrm{ab}}$ \\
\hline 0.03 & $2.34 \pm 0.31^{\mathrm{a}}$ & $2.00 \pm 0.31^{\mathrm{ab}}$ & $6.50 \pm 0.58^{b}$ & $1.18 \pm 0.81^{\mathrm{ab}}$ \\
\hline 0.07 & $2.03 \pm 0.19^{\mathrm{a}}$ & $2.25 \pm 0.19^{b c}$ & $5.50 \pm 0.58^{c}$ & $0.81 \pm 0.47^{\mathrm{ab}}$ \\
\hline 0.1 & $2.20 \pm 0.42^{\mathrm{a}}$ & $0.50 \pm 0.42^{\mathrm{b}}$ & $5.25 \pm 0.50^{\mathrm{c}}$ & $0.51^{\mathrm{b}}$ \\
\hline
\end{tabular}

Table Four: $\quad$ Effect of salt stress on nitrogen assimilation of leaf samples of A. hypogea and soil

\begin{tabular}{lll}
\multicolumn{3}{c}{ samples } \\
\hline Concentration (mol/L) & \multicolumn{2}{c}{ Nitrogen Assimilation } \\
\cline { 2 - 3 } & Leaf samples & Soil samples \\
\hline Control & $4.14 \pm 1.02^{\mathrm{a}}$ & $0.77 \pm 0.02^{\mathrm{b}}$ \\
0.02 & $3.89 \pm 0.05^{\mathrm{b}}$ & $0.574 \pm 0.03^{\mathrm{b}}$ \\
0.03 & $3.05 \pm 1.01^{\mathrm{c}}$ & $1.04 \pm 0.08^{\mathrm{a}}$ \\
0.07 & $2.82 \pm 0.04^{\mathrm{d}}$ & $1.00 \pm 0.06^{\mathrm{a}}$ \\
0.1 & $2.77 \pm 0.02$ & $0.93 \pm 0.01^{\mathrm{a}}$ \\
\hline
\end{tabular}




\section{References:}

[1]. Agrawal, R. L. (1995). Seed Technology(Second Edition). Oxford and IBH Publishing company PVT Ltd. New Delhi India Pp 878

[2]. Association of Official Analytical Chemist (AOAC) (1990). Official methods of Analysts (15 Edn) Washington.

[3]. Ashraf, M. (1994). Organic Substances Responsible for Salt Tolerance in Eruca Sativa. Boil. Plant. 36: 255 - 259.

[4]. Boscaiu, M., Estrelles, E., Soriano, P. and Vicente, O. (2005). Effects of salt stress on the reproductive biology of the halophytes Plantagocrassifolia.BiologiaPlantarum 49(1): $141-143$.

[5]. Bray, E. A., Bailey-Serres and Weretilnyk, E. (2000). Responses to Abiotic Stress. In: Buchanan, B. Gruissem W. and Jones R. (eds), Biochem. Mol. Biol. Plants. Amr. Soc. Plant. Physiol, Rockville, Pp. 1158 - 1203.

[6]. Chartzoulakis, K. and Klapaki, G. (2000). Response of two green house pepper hybrids to $\mathrm{NaCl}$ salinity different growth stages. ScientiaHorticulturae, 86 (3): 247- 260

[7]. Cuartero, J. and Fernandez- Munoz (1998). Tomato and salinity. ScientiaHorticulturae, 78(1-4): 83- 125.

[8]. Cordovilla, M. P., Ligero, F., Wuch, C. (1995). Influence of Host Genotypes on Growth, Symbiotic Performance and Nitrogen Assimilation in Faba Bean (Viciafaba L.) under salt stress. Plant Soil. 172: 289 - 297.

[9]. Demiral, T. and Turkan, I. (2006). Exogenous Glycinebetaine Affects Growth and Proline Accumulation and Retards Senescence in Two Rice Cultivars under NaCl Stress. Environ. Exp. Bot. 56 (1): 72 - 79.

[10]. Elsheikh, E. A. E.and Wood, M. (1990). Effect of Salinity on Growth, Nodulation and Nitrogen Yield of Chickpea (Cicerarietinum L.). J. Exp. Bot. 41: $1263-1269$.

[11]. Gregory, W. C. Gregory, M. P., Krapvicks A., Smith, B. W. and Yarbrough, J. A. (1973). Structures and genetic resources of peanuts. In peanuts - Culture and Uses.47 - 137 American Peanut Research and Education Association.

[12]. Kaya, C., Kirnak, H. et al. (2001). Enhancement of Growth and Normal Parameters By Foliar Application of Potassium and Phosphorus in Tomato Cultivars grown at High (NaCl) Salinity. J. Plant Nutr. 24 (2): 359 - 367.

[13]. Khan, M. A., Ungar, I. A., et al. (2000). Effects of Sodium Chlordide Treatment on Growth and Ion Accumulation of the Halophy te Haloxylonrecurvum. Common. Soil. Sci. Plant Anal. 31 (17-18): 2763 - 2774

[14]. Khanna-Chopra, R. and Sinha, S. K. (1998). Prospects of Success of Biotechnological Approaches for Improving Tolerance to Drought Stress in Crop Plants. Curr. Sci. 74 (1): 25 - 34.

[15]. Maggio, A., Raimondi, G., Martino, A. and De Pascale S. (2007). Salt Stress Response in Tomato Beyond the Salinity Tolerance Threshold. Environ. Exp. Bot., 59 (3): $276-282$.

[16]. Motahari, M., Namaki, S. A., Kalantari, K. U. M. (2005). Effects of salinity on growth and nitrogen fixation of two cultivars of alfalfa inoculated by different strains of Sinorhizobiummeliloti.

[17]. Mundree, S. G., Baker, B., Mowla, S., Peters, S., Vander Willigen, C., Govender, K., Maredza, A., Muyanga, S., Farran, J. M. and Thomson, J. A. (2002). Physiological and Molecular Insights into Drought Tolerance. Afr. J. Biotechnol. 1, 28 - 38.

[18]. Munns, R. (2002). Comparative Physiology of Salt and Water Stress - Plant Cell Environ. 25: 239 - 250.

[19]. Neocleous D. and Vasilakakis, M. (2007). Effects of NaCl Stress onRed Raspberry (Rubusidaeus L 'Autumn Bliss') Sci. Hort., 112: $282-289$.

[20]. Niu, X., Bressan, R. A, Hasegwa, P. M. and Pardo, J. M. (1995). Ion Homeostatis in NaCl Stress Environments. Plant Physiol. 109, $735-742$

[21]. Parida, A. K., Das, A. B. (2004). Effects of Salt on Growth, Ion Accumulation Photosynthesis and Leaf Anatomy of the Mangrove, Bruguieraparviflora. Trees-Struct. Funct. 18 (2): $167-174$

[22]. Parida, A. K. and Das, A. B. (2005). Salt Tolerance and Salinity Effects on Plants. A Rev. Ecotoxicol.Environ. Safety. 60: 324 349 .

[23]. Pitman, M. G. and Lauchi, A. (2002). Global Impact of Salinity and Agricultural Ecosystems. Salinity: Environment - Plants Molecules. Springer, Netherlands. Pp. $3-20$.

[24]. Ramoliya, P. J., Patel, H. M. et al., (2004). Effect of Salinization of Soil on Growth and Macro and Micro-Nutrient Accumulation in Seedlings of Salvadorapersica (Salvadoraceae). Forest Eco. Manage., 202 (1-3): 181 - 193.

[25]. Sacala, E., Demczuk, A., Grzys, E. and Spaik, Z. (2008). Effect of salt and water stresses on growth, nitrogen and phosphorus metabolism in Cucumissativus L. seedling. ActasocietatisBotanicorumPoloniae, 77(1): 23- 28.

[26]. Sharma, K. K. and Bhatnagar- Mathur, P. (2006). Peanut (Arachis hypogea L).Methods Mol. Biol, $343: 347-358$.

[27]. Soussi, M., Ocana, A., Wuch, C. (1998). Effect of Salt Stress on Growth, Photosynthesis and Nitrogen Fixation in Chickpea (Cicerarietinum L.). J. Exp. Bot. 49: 1329-1337.

[28]. Spark, D. L. (1995). Environmental soil chemistry. Academic Press, London UK

[29]. Sula Rao, N. S., Johansen, C., Kumar Rao, J. V. and Jana, M. K. (1990). Response of the Pigeon Pea - Rhizobium Symbiosis to Salinity Stress. Variation among Rhizozobium Strain in Symbiotic Ability. Biol. Fertil. Soil., 9: $49-53$.

[30]. Teas, H. J. (1983). Biology and Ecology of Mangroves. W. Junk Publishers, The Hague. Pp. 5 - 9.

[31]. Zou, N., Part, P. J. and Marcar, N. E. (1995). Interaction of Salinity and Rhizobial Strain on Growth and $\mathrm{N}_{2}$ Fixation by Acacia ampliceps, Soil. Biol. Biochem. 27: (4/5): $409-413$. 